\title{
Preparation and Characterization of Cellulose Nanocrystals Reinforced Poly (vinyl alcohol) Based Hydrogels for Drug Delivery System ${ }^{1}$
}

\author{
Hyejung $\mathrm{CHO}^{2} \cdot$ Won-Jae $\mathrm{YOO}^{2} \cdot$ Jinsoo $\mathrm{AHN}^{2} \cdot$ Sang-Jin $\mathrm{CHUN}^{3}$ • \\ Sun-Young $\mathrm{LEE}^{4} \cdot$ Jaegyoung GWON ${ }^{2, \dagger}$
}

\begin{abstract}
Structural property of most hydrogels is soft, resulting in low mechanical performance that limits their usage in the biomedical applications. For overcoming the drawback, cellulose nanocrystals (CNCs) were adopted in this study. Effects of CNCs on characteristics and drug delivery performance of poly (vinyl alcohol) based hydrogels were explored. FT-IR results showed that the fabricated hydrogels had semi-IPN (semi-interpenetrating polymer network) by formation of acetal and aldehyde bridge. Water absorption and swelling ratio decreased with increasing CNCs content, and the hydrogels with CNCs showed better viscoelastic performance than the without CNCs. Also, CNCs mostly improved the ability of the hydrogel to absorb the drug and the sustainability of the drug release. These results demonstrated that incorporating CNCs into the hydrogel systems can be a good alternative to improve drug delivery performance and mechanical property of the hydrogels.
\end{abstract}

Keywords: hydrogels, poly (vinyl alcohol), cellulose nanocrystals (CNCs), drug delivery system

\section{INTRODUCTION}

Drug delivery system (DDS) is a route of administration and the type of the drug to deliver the appropriate amount of the drug in a way that minimizes adverse effects and maximizes its efficacy (Rivas et al., 2017). To do so, it needs to enhance stability and efficiency by controlling spatio-temporal variability of drug efficacy by an improved drug delivery system.
When the hydrogels absorbed large amounts of water, they behave like living tissues. Because they form a 3D scaffold with physical and chemical cross-links, this characteristic allows application of drug delivery system with high biocompatibility (An et al., 2017; Valle et al., 2017; Tanpichai and Oksman, 2016; Xiao and Zhou, 2013; Li and Mooney, 2016; Hyon et al., 1989; Pal et al., 2016). However, a low tensile strength of the hydrogels limits its application in parts that re-

\footnotetext{
${ }^{1}$ Date Received March 6, 2020, Date Accepted May 4, 2020

2 Division of Wood Chemistry, Department of forest Products, National Institute of Forest Science, Seoul 02455, Republic of Korea

${ }^{3}$ Division of Wood Utilization, Department of forest Products, National Institute of Forest Science, Seoul 02455, Republic of Korea

${ }^{4}$ Forest Biomaterials Research Center, National Institute of Forest Science, Jinju 52817, Republic of Korea

$\dagger$ Corresponding author: Jaegyoung Gwon (e-mail: gwonjg@korea.kr, ORCID: 0000-0003-4914-709X)
} 
Hyejung CHO $\cdot$ Won-Jae YOO $\cdot$ Jinsoo AHN $\cdot$ Sang-Jin CHUN $\cdot$ Sun-Young LEE $\cdot$ Jaegyoung GWON

quires structural bearing power and decomposes quickly at a target point through an early melting process.

Also, it has been pointed out as disadvantages for industrial use of hydrogels that it is hard to load drugs in a hydrogel, which has a high water content and a porous structure, and it has a rapid release due to osmotic pressure (Rivas et al., 2017; McKenzie et al., 2015). For those reasons, some studies have been conducted by molding hydrogels, combining in various ways to improve mechanical strength (Wang et al., 2010; Hyon et al., 1989), and preparing a membranetype with a multi-layered structure to facilitate hydrophobic compounds binding to the internal cavity (Ladet et al., 2008; Lin et al., 2006; Zawko et al., 2008).

$\mathrm{CNCs}$, which are organic-based nanomaterials produced using cellulose widely present in nature, were added to biodegradable PVA and applied to a hydrogel system. It is expected to improve the hydrogel's mechanical properties, increase the loading efficiency of hydrophobic drugs, and show a delayed release effect. The CNCs produced by acid hydrolysis are derived from sulfuric acid, and it features a length and thickness of $300 \mathrm{~nm}$ and 5-70 nm or less, respectively, resulting in a high surface area-to-volume ratio. It is easier to modify chemically than cellulose nanofiber (CNF), also based on nanocellulose, with a higher crystallinity and a higher reactivity due to many hydroxyl groups $(-\mathrm{OH})$ on the surface. Therefore, it has been spotlighted as an eco-friendly reinforcement in the high-molecule composite material field (Gwon et al., 2016; Gwon et al., 2018; Khanjanzadeh and Park 2020; Zaini et al., 2019). In particular, CNCs can absorb large amounts of water due to their high specific surface area and numerous hydroxyl groups, and the sulfate $\left(\mathrm{SO}^{2-}\right)$ formed on the surface by sulfuric acid treatment can maximize the efficiency of adsorption and delayed release of hydrophobic drugs. Therefore, application of CNCs is expected to be a good solution in terms of improving the mechanical properties and drug delivery efficiency of hydrogels.
In this study, CNC was applied to the PVA hydrogel system in which glutaraldehyde (GA) was used as a crosslinking agent, and the adsorption and release behavior of the drug was examined after salicylic acid (SA) was introduced as a drug model. To evaluate the structural properties of the hydrogel, fourier transform infrared (FT-IR) spectroscopy, water content, swelling ratio, specific surface area, scanning electron microscopy (SEM) and viscoelastic properties were analyzed. In addition, Langmuir, Freundlich adsorption model was applied to see interaction between hydrogels and the drug, and Lagergren's pseudo $1^{\text {st }}$ order model and Ho's pseudo $2^{\text {nd }}$ order model were applied for the release behavior.

\section{MATERIALS and METHODS}

\subsection{Materials}

In this study, hydrogel was prepared by adding CNCs, a crystalline polymer, to PVA (Mowiol ${ }^{\circledR} 10$ 98, Sigma-aldrich), having a molecular weight of 61,000 Da, and glutaraldehyde (GA, Sigma-aldrich) was used as a crosslinking agent. The CNCs used in this study are made from cellulose powder (KC Flock W-50, average size: $45 \mu \mathrm{m})$ purchased from Nippon Paper Chemicals Co., Ltd. (Tokyo, Japan). And then, by the same method as in the previous study (Gwon et al., 2016; Gwon et al., 2018), the hydrolysis treatment was performed with 64 wt.\% sulfuric acid $\left(\mathrm{H}_{2} \mathrm{SO}_{4}\right.$, Junsei, Japan) for 20 minutes at $45^{\circ} \mathrm{C}$, followed by washing with water until the supernatant became neutral by centrifugation. The CNCs/PVA suspension with distilled water used as a solvent was adjusted to $\mathrm{pH} 4.0 \pm 0.2$. GA was added and $0.5 \mathrm{~N} \mathrm{HCl}$ (0.5N-Hydrochloric acid standard solution, Daejung Chemicals \& Metals Co., Ltd, Korea) was used as a catalyst to induce binding reaction of $\mathrm{pH} 2.0 \pm 0.02$, preparing the hydrogels. And then, drug loading and release characteristics of the hydrogel prepared using 
salicylic acid (salicylic acid, $\geq 99.0 \%$, Sigma-aldrich), one of the hydrophobic low-molecular-weight drugs, were observed.

\subsection{Preparation of CNCs-based PVA Hydrogels}

The suspension was prepared as follows: After double-boiling 5wt.\% PVA hydrogels with $200 \mathrm{~mL}$ of distilled water at $70{ }^{\circ} \mathrm{C}$ to melt, it was prepared with varying $\mathrm{CNCs}$ loading corresponding to 0,10 , and $20 \mathrm{phr}$ of the dry weight, and stirred at $200 \mathrm{rpm}$ for 6 hours. It was marked as $\mathrm{CNC} 0, \mathrm{CNC} 10$, and $\mathrm{CNC} 20$ depending on CNCs content. Each suspension having a different CNCs content was sufficiently stirred to prepare CNCs-PVA suspension with the CNCs were evenly distributed, and cooled in a desiccator to room temperature. GA of 5 phr (part per hundred resin) to PVA was added in the dripping method to the CNCs/PVA suspension and stirred for 5 minutes. After $\mathrm{pH}$ was adjusted to $2.0 \pm$ 0.02 with $0.5 \mathrm{~N} \mathrm{HCl}$ added, it was cured for 48 hours at room temperature in a $20 \mathrm{~mm}(\mathrm{~d}) \times 8 \mathrm{~mm}$ (h) aluminum mold. The surface of the prepared hydrogels was washed with distilled water to remove unreacted cross-linking agents remaining on the surface after synthesis reaction and $0.5 \mathrm{~N} \mathrm{HCl}$ used for $\mathrm{pH}$ adjustment until the surface turned neutral, and the finished specimens were stored in a chamber at $5{ }^{\circ} \mathrm{C}$ for use. The hydrogels were prepared in the same composition as described in Table 1. Fig. 1, shows that transparency decreased as the CNCs content increased, and no color change occurred.

Table 1. Component of PVA/CNCs/GA hydrogels

\begin{tabular}{ccccc}
\hline \multirow{2}{*}{$\begin{array}{c}\text { Sample } \\
\text { name }\end{array}$} & \multicolumn{4}{c}{ Component } \\
\cline { 2 - 5 } & PVA (wt\%) & CNCs (phr) & GA (phr) & $\mathrm{pH}$ \\
\hline \hline CNC0 & 5 & 0 & 5 & $2.0 \pm 0.02$ \\
$\mathrm{CNC} 10$ & 5 & 10 & 5 & $2.0 \pm 0.02$ \\
$\mathrm{CNC} 20$ & 5 & 20 & 5 & $2.0 \pm 0.02$ \\
\hline
\end{tabular}

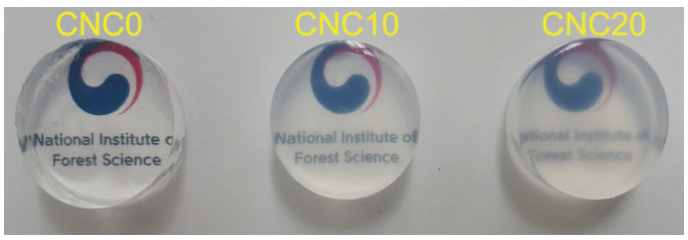

Fig. 1. Visual appearance of prepared PVA based hydrogels incorporated with CNCs.

\subsection{Characterization of $\mathrm{CNCs}-$ based PVA hydrogels}

\subsubsection{Specific surface area and scanning electron microscopy analysis}

The prepared hydrogels were rapidly frozen under a liquid nitrogen atmosphere, stored in a freezer at $-60{ }^{\circ} \mathrm{C}$, and dried using a freeze dryer (FDU-1200, Eyela, Tokyo, Japan). The freeze-dried specimen was degassed at $20{ }^{\circ} \mathrm{C}$ for 30 minutes to remove residual moisture, and then specific surface area was measured with the nitrogen adsorption/desorption method (ASAP 2420, Micromertics ${ }^{\circledR}$, United State) for 5 hours with liquid nitrogen.

The surfaces of the freeze-dried specimens were coated with thin gold films of $2 \mathrm{~nm}$ (Ion-Coater (KIC-IA), Coxem, Korea) by sputtering for $200 \mathrm{sec}-$ onds at $4 \mathrm{~mA}$, measured using FE-SEM (Coxem-30, Coxem, Korea), and different hydrogel images were obtained with different CNCs content.

\subsubsection{Chemical functional group analysis}

An infrared spectrophotometer FT-IR (Nicolet iS10 FT-IR Spectrometer, Thermo Scientific, United State) was used to verify interfacial properties of the hydrogels with drug loaded and the ones without drug. All samples were used after surface was washed and dried for 24 hours in a chamber at $70{ }^{\circ} \mathrm{C}$. However, the drug-loaded hydrogels were immersed in the drug for 48 hours in a chamber at $37{ }^{\circ} \mathrm{C}$ before beingwashed with distilled water to remove residuals on the surface until the hydrogel surface was neutral. FT-IR 
Hyejung CHO $\cdot$ Won-Jae YOO $\cdot$ Jinsoo AHN $\cdot$ Sang-Jin CHUN $\cdot$ Sun-Young LEE $\cdot$ Jaegyoung GWON

analysis was conducted in the ATR mode, the scan range of $400 \sim 4000 \mathrm{~cm}^{-1}$, the total scan of 32 , the resolution of $8 \mathrm{~cm}^{-1}$.

\subsubsection{Water content and swelling ratio test of CNCs-based PVA hydrogels}

To confirm the water content of the CNCs-based PVA hydrogels, thoroughly washed hydrogels were placed in a chamber at $70{ }^{\circ} \mathrm{C}$, completely dried for 24 hours, and the weight difference was measured before and after drying using an analytical balance (HR-250AZ, A\&D Co., Ltd., Korea). The weight was measured three times to be determined with the error range of $\pm(0.1 \%)$.

Weight remaining $(\%)=\left(\mathrm{W}_{\mathrm{i}}-\mathrm{W}_{\mathrm{d}}\right) / \mathrm{W}_{\mathrm{i}} \times 100$

$\mathrm{W}_{\mathrm{i}}$ : Initial weight of hydrogels

$\mathrm{W}_{\mathrm{d}}$ : Weight of dried hydrogels

To check swelling properties, the hydrogels dried for 12 hours in a chamber at $70{ }^{\circ} \mathrm{C}$ were immersed in distilled water at $37{ }^{\circ} \mathrm{C}$. The purpose was to check the swelling ratio according to the weight by time compared to the initial weight. The weight was measured three times to be determined in the error range of $\pm(0.1 \%)$.

Swelling ratio $(\%)=\left(\mathrm{W}_{\mathrm{s}}-\mathrm{W}_{\mathrm{d}}\right) / \mathrm{W}_{\mathrm{d}} \times 100$

$\mathrm{W}_{\mathrm{d}}$ : Weight of dried hydrogels

$\mathrm{W}_{\mathrm{s}}$ : Weight after swollen

\subsubsection{Mechanical properties of CNCs-based PVA hydrogels}

To evaluate mechanical properties of hydrogels by CNCs content, CNCs-based PVA hydrogels' storage modulus and loss modulus were analyzed using parallel and peltier plates with DHR3 rheometer (TA instruments, US). It was measured in the range of $0.1 \sim 100$ radius/s for frequency sweep, $0.5 \mu \mathrm{N}$ of axial force, and $10 \%$ of strain at $25{ }^{\circ} \mathrm{C}$.
The storage modulus and loss modulus were determined with the following equation (Wang et al., 2010).

$$
\begin{array}{r}
\text { Storage Modulus, } G^{\prime}(P a)=\frac{\sigma}{\epsilon} \cdot \cos \theta \\
\text { Loss Modulus, } G^{\prime \prime}(P a)=\frac{\sigma}{\epsilon} \cdot \sin \theta
\end{array}
$$

$\sigma:$ Shear stress

$\varepsilon$ : Shear strain

\subsubsection{Drug loading and release CNCs-based PVA hydrogels}

Salicylic acid, which is one of hydrophobic low-molecular-weight drugs, was used to study the same type of drugs that have difficulties in fast release and loading. For the loading experiment, the hydrogels immersed in distilled water for 48 hours in a chamber at $37{ }^{\circ} \mathrm{C}$ and swollen to $20 \pm 2 \varnothing$ diameter, $8 \pm 2$ $\mathrm{mm}$ height, and $1.45 \pm 0.1 \mathrm{~g}$ weight were impregnated with $200,500,1000$, and $2000 \mathrm{mg} / \mathrm{L}$ of different concentrations of the drug. The amount of loaded drug was measured by HPLC (High Performance Liquid Chromatography, 1260 Series, Agilent).

The amount of the drug loaded per unit weight of CNCs-based PVA hydrogel was calculated with the following equation.

$$
\mathrm{q}_{\mathrm{e}}=\left(\mathrm{C}_{\mathrm{i}}-\mathrm{C}_{\mathrm{e}}\right) \times \mathrm{V} / 1000 \mathrm{w}
$$

V: Volume of drug solution $(\mathrm{mL})$

w: Weight of hydrogel (g)

$\mathrm{C}_{\mathrm{i}}$ : Concentration of initial drug $(\mathrm{mg} / \mathrm{L})$

$\mathrm{C}_{\mathrm{e}}$ : Concentration of drug at equilibrium $(\mathrm{mg} / \mathrm{L})$

$\mathrm{q}_{\mathrm{e}}$ : Concentration at equilibrium after loading of the drug per unit weight of hydrogels $(\mathrm{mg} / \mathrm{g})$

In order to obtain process parameters for applying the drug-loaded hydrogels to the drug system by the impregnation method, the appearance of the hydrogel interface and drug loading were predicted using an adsorption isotherm model. The interfacial reaction between the hydrogels and the drug was observed by using Langmuir isotherm, which is composed of a mono- 
layer on a single interface and mainly shown in chemical bonds, and Freundlich isotherm, where a drug combines on a heterogeneous interface with multilayers by physical adsorption (Cho et. al., 2013).

Langmuir isotherm is as follows:

$$
\begin{gathered}
q_{e}=\frac{q_{\mathrm{max}} b C_{e}}{1+b C_{e}} \quad \text { by linearization, } \\
\frac{C_{e}}{q_{e}}=\frac{1}{b \cdot q_{\max }}+\frac{C_{e}}{q_{\max }}
\end{gathered}
$$

$q_{\mathrm{e}}$ : Concentration at equilibrium after loading of the drug per unit weight of hydrogels $(\mathrm{mg} / \mathrm{g})$

$C_{\mathrm{e}}$ : Concentration of drug at equilibrium $(\mathrm{mg} / \mathrm{L})$

$q_{\text {max }}$ : Maximum amount of the drug per unit weight of hydrogels (mg)

b: Langmuir adsorption constant

Langmuir isotherm is as follows:

$$
\begin{gathered}
q_{e}=K_{F} C_{e}^{1 / n} \quad \text { by linearization, } \\
\log q_{e}=\log K_{F}+\frac{1}{n} \log C_{e}
\end{gathered}
$$

$q_{\mathrm{e}}$ : Concentration at equilibrium after loading of the drug per unit weight of hydrogels $(\mathrm{mg} / \mathrm{g})$

$C_{\mathrm{e}}$ : Concentration of drug at equilibrium $(\mathrm{mg} / \mathrm{L})$

$K_{\mathrm{F}}$ : Freundlich adsorption constant

$n$ : Adsorption constant from Freundlich isotherm

To verify the release behavior of the drug, the following environment was provided: the hydrogels were exposed for 48 hours to the condition where the drug concentration was $2000 \mathrm{mg} / \mathrm{L}$ to load them completely; the hydrogels loaded with the drug to have $20 \pm 2$ $\mathrm{mm}$ diameter, $8 \pm 2 \mathrm{~mm}$ height, and $1.45 \pm 0.1 \mathrm{~g}$ weight were completely immersed in $10 \mathrm{~mL}$ of distilled water in a chamber at $37^{\circ} \mathrm{C}$, which is similar to the body temperature, and stirred at $50 \mathrm{rpm}$ so that the drug could be sufficiently released. HPLC (High Performance Liquid Chromatography, 1260 Series, Agilent, United State) was used to evaluate the concentration of the drug released per unit weight by time.

Pseudo $1^{\text {st }}$ order model and pseudo $2^{\text {nd }}$ order model were applied to dynamically analyze the drug release properties in drug-loaded CNCs-based PVA hydrogels over time.

Pseudo $1^{\text {st }}$ order equation is as follows:

$$
\begin{gathered}
\frac{d q_{t}}{d_{t}}=k_{1}\left(q_{e}-q_{t}\right) \quad \text { by linearization, } \\
\log \frac{q_{e}}{\left(q_{e}-q_{t}\right)}=\frac{k_{1} t}{2.303}
\end{gathered}
$$

$q_{\mathrm{e}}$ : Released amount during equilibrium (mg/g)

$q_{\mathrm{t}}$ : Released amount per unit time $(\mathrm{mg} / \mathrm{g})$

$k_{1}$ : Rate constant of the pseudo-first-order model

$t$ : Reaction time

Pseudo $2^{\text {st }}$ order equation is as follows:

$$
\begin{gathered}
\frac{d q_{t}}{d_{t}}=k_{2}\left(q_{e}-q_{t}\right)^{2} \quad \text { by linearization, } \\
\frac{1}{q_{e}-q_{t}}=\frac{1}{q_{e}}+k_{2} t
\end{gathered}
$$

$q_{\mathrm{e}}$ : Released amount during equilibrium (mg/g)

$q_{\mathrm{t}}$ : Released amount per unit time $(\mathrm{mg} / \mathrm{g})$

$k_{2}$ : Rate constant of the pseudo-second-order model

$t$ : Reaction time

Additionally, the initial release rate (h) with $h=k_{2} q_{e}^{2}$ was obtained from the pseudo $2^{\text {nd }}$ order equation (Cho et al., 2013).

Salicylic acid was analyzed by HPLC as described in Table 2.

Table 2. Analytical condition of HPLC

\begin{tabular}{ll}
\hline \multicolumn{1}{c}{ Conditions } \\
\hline \hline Column & $\begin{array}{l}\text { Kinetex C18 }(4.6 \times 250 \mathrm{~mm}, 5 \mu, \\
\text { Phenomenex })\end{array}$ \\
$\begin{array}{l}\text { Guard column } \\
\text { UHPLC C18 (AJ0-8768, Phenomenex) } \\
\text { Telumn }\end{array}$ & $25^{\circ} \mathrm{C}$ \\
Mobile phases & A $(0.1 \%$ phosphoric acid 30$):$ \\
Flow rate & B (Acetonitrile 70) \\
Wavelength & $1.0 \mathrm{~mL} / \mathrm{min}$ \\
Injection volume & $10 \mu \mathrm{L}$ \\
\hline
\end{tabular}




\section{RESULTS and DISCUSSION}

\subsection{Chemical and morphological properties}

The FT-IR spectra of the prepared CNCs-based PVA hydrogels loaded with the drug is shown in Fig. 2. As expected, the peak intensity of the $3000-3600 \mathrm{~cm}^{-1}$ region representing a free-OH group increased due to the addition of CNCs. Also, a - $\mathrm{CH}$ stretching vibration band in the $2930 \mathrm{~cm}^{-1}$ range, a C-H stretching band in the range of $2750 \sim 2850 \mathrm{~cm}^{-1}$ that are peaks seen in the aldehyde group, and a $\mathrm{C}=\mathrm{O}$ vibration band in the range of 1720 to $1740 \mathrm{~cm}^{-1}$ appeared (Reis et al., 2006; Mansur et al., 2008; Hendrawan et al., 2019; Marin and Rojas, 2015). In particular, unloaded hydrogels showed the $\mathrm{C}=\mathrm{O}$ groups that did not react to the cross-linking agent in the range of 720 to $1740 \mathrm{~cm}^{-1}$, but the peak intensity of loaded hydrogels decreased near $1700 \mathrm{~cm}^{-1}$ (Thangprasert et al., 2019). Also, peaks of acetal and ether groups formed by cross-link between the aldehyde group (-CHO) of GA and the hydroxyl group (-OH) of PVA and CNCs are shown in the regions of $1371 \mathrm{~cm}^{-1}, 1250 \mathrm{~cm}^{-1}$, and $950 \mathrm{~cm}^{-1}$ (Yue et al., 2016; Yeom and Lee, 1996; Kim et al., 2003). The presence of the aldehyde group implies that there is an incomplete hemi-acetal linkage where only one of the two functional groups of GA is combined. Although the hemi-acetal group exists, the formation of the acetal and ether groups shows that the hydrogels prepared in this study using one type

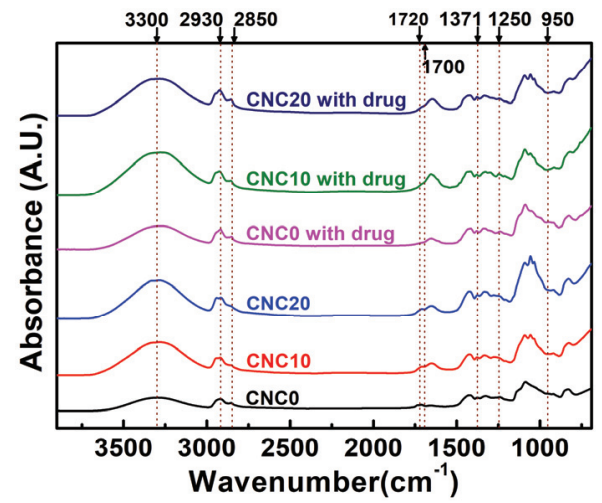

Fig. 2. FTIR spectra of the PVA/varied CNCs content/ GA hydrogels with/without drugs.

of polymer formed a 3D cross-linked network (semiIPN) (Yue et al., 2016).

Fig. 3 shows SEM images that were measured to verify the $3 \mathrm{D}$ scaffold network (semi-IPN) of the hydrogels. From these results, it was concluded that PVA, CNCs and GA had a 3D pore structure interconnected by crosslinking between hydroxyl groups, and the size of the pores increased as the content of CNCs increased.

\subsection{Water content and swelling ratio}

The hydrogels play a role as a release control through an expansion of polymer chains by water absorption, and it affects drug diffusion, especially release behavior. The release rate is determined by an ability of solvent molecules to move through the gel
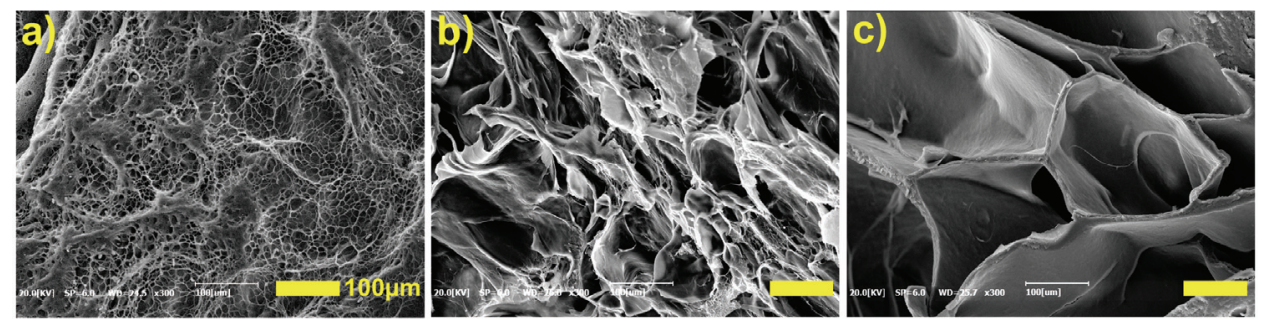

Fig. 3. SEM images of the PVA/CNCs/GA hydrogels (a) $\mathrm{CNC} 0$ (b) $\mathrm{CNC} 10$ (c) $\mathrm{CNC} 20$ with magnitude $\mathrm{x} 300$. 

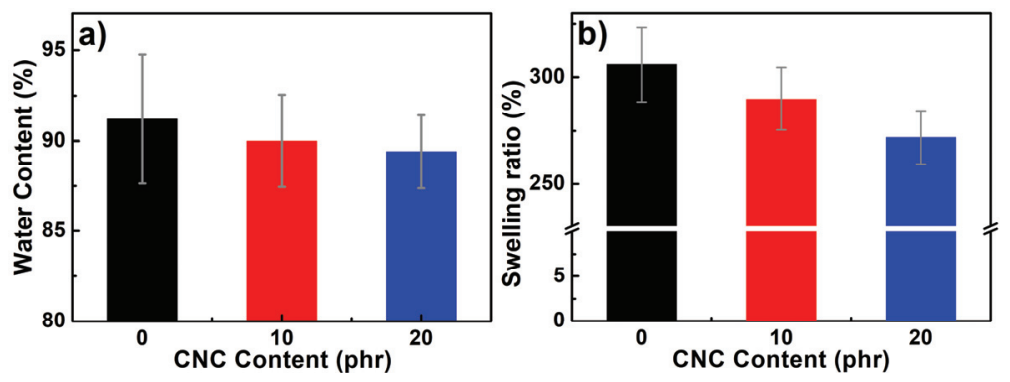

Fig. 4. Water content and Swelling ratio of the $\mathrm{PVA} / \mathrm{CNCs} / \mathrm{GA}$ hydrogels with varied $\mathrm{CNCs}$ content.

network, and the structure morphologically changes during the gel is swollen by diffusion through the polymer chains and strain relaxation between the chains (Mansur et al., 2008). Therefore, it is important to understand water content and swelling ratio properties for the following salicylic acid drug release behavior study. The water content and swelling ratio of the hydrogels were evaluated, and the properties change due to water absorption was observed. The results are presented in Fig. 4. As the CNCs content increased from 0 , to 10 and $20 \mathrm{phr}$, the water content decreased from 91.2 to 90.0 and $89.4 \%$ and the swelling ratio from 306 to 290 and $272 \%$. Noteworthy, both water content and swelling ratio tend to slightly decrease as the $\mathrm{CNC}_{\mathrm{S}}$ increase. As found in Fig. 2, the addition of $\mathrm{CNCs}$ is supposed to increase hydrophilic free-OH groups in the light of surface affinity perspective. Contrary to expectations, however, the water content decreased as the CNCs increased. The decrease of the swelling ratio can be affected by a spatial restrictioninside the hydrogels. In the case of a polymer mixed with a good solvent, as the chain entanglement is detangled and loosened, they can move freely and allows a large amount of solvent molecules to get in the spaces between the chains. Accordingly, the chains occupy morefree space, and when solid particles with high crystallinity are inserted between the polymer chains, their movement decrease, reducing their freedom. Especially, the similar characteristic of the sur- face between CNCs and PVA enhances its bonding, so the internal structure of the prepare hydrogels can be denser and more compact (Masruchin et al., 2015). For that reason, it was concluded that addition of CNCs inhibited PVA chain mobility, leading to a decrease in water content and swelling ratio. In terms of drug delivery, the higher the amount of water the hydrogels contain, the more drugs hydrogelscan store inside (Hoare and Kohane, 2008). Adding CNCs tends to speed up the initial water absorption because of many free-OH groups on the surface (Masruchin et al., 2015), but it has no positive effect on improving drug loading by volume increment of hydrogels.

\subsection{Mechanical properties}

Storage modulus $\left(\mathrm{G}^{\prime}\right)$ and loss modulus $\left(\mathrm{G}^{\prime \prime}\right)$ were studied by viscoelastic propertyanalysis, and the mechanical properties of CNCs-based PVA hydrogels were described in Fig. 5. It was founded that $G^{\prime}$ had a higher value that $\mathrm{G}^{\prime \prime}$ over the change of $\omega$ (angular frequency), and the prepared hydrogels have strong solid behavior (Yue et al., 2016). As it was explained in Section 3.1, it was caused by the formation of a 3D scaffold network (semi-IPN) cross-linked between acetal, ether, and hydrogen and polymer chains. Especially, all the viscoelasticity properties tend to increase with $\mathrm{CNC}$ content, which is caused by the $\mathrm{CNCs}$ with a large specific surface and a large amount of hydrox$\mathrm{yl}$ groups acting as a reinforcement by penetrating 


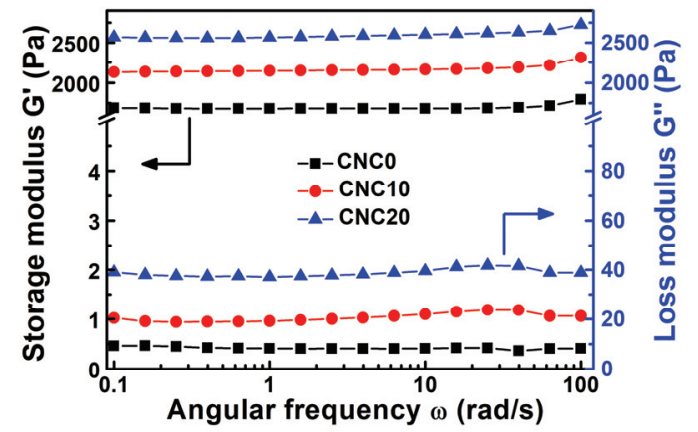

Fig. 5. Frequency sweep test of storage modulus $\left(\mathrm{G}^{\prime}\right)$ and loss modulus (G") of the PVA/CNCs/GA hydrogels with varied CNCs content.

between PVA chains and strengthen physical and chemical binding and entanglement to restrict the molecule chains and distribute stress on the hydrogels and improve mechanical properties. Also, it was noted that a certain level of linear viscoelastic region (LVR) can be formed regardless of $\omega$. If the forces applied inside the molecules are concentrated in a specific area without uniform dispersion, non-constant and irregular fluctuation of $\mathrm{G}^{\prime}$ may occur due to complete or partial destruction of the intramolecular or intermolecular bonds at low $\omega$ (Mezger, T., 2016, Yue et al., 2016). Consequently, the stable formation of LVR throughout the $\omega$ region in hydrogels with $\mathrm{CNCs}$ implies that CNCs are evenly distributed between the PVA chains.

\subsection{Drug loading properties}

In this study, the drug loading performance was investigated using Langmuir isotherm and Freundlich isotherm as adsorption isotherm models. And the results are shown in Fig. 6a with salicylic acid loading amount by different concentration and the CNCs content. It was confirmed that moresalicylic acid was loaded on hydrogels with the CNCs than those without the CNCs, and the hydrogels with $10 \mathrm{phr}$ added loaded a slightly more amount than those with $20 \mathrm{phr}$ added. First of all, similar to the water content and swelling ratio characteristics mentioned above, it was founded that, despite the hydrogel without $\mathrm{CNCs}$ having more internal space, the hydrogel with CNCs loaded more drugs. Generally, the amount of adsorption increases on the interface as the surface area increases on the surface bonding mechanism (Zhou et al., 2015; Gao et al., 2017). From these results, the specific surface and pore volume were derived to calculate the surface are to pore volume ratio by the Baunauer-EmmettTeller (BET) equation usingnitrogen adsorption/desorption method described in Section 2.3.1, and the results are presented in Fig. 7. Surface areasper unit volume $\left(1 \mathrm{~cm}^{3}\right)$ were 314,677 , and $61 \mathrm{~m}^{2}$ when respectively $\mathrm{CNC} 0, \mathrm{CNC} 10$, and $\mathrm{CNC} 20$ were added into the hydrogels. From these results, $\mathrm{CNC} 10$ was able to adsorb a large amount of the drug and the inner
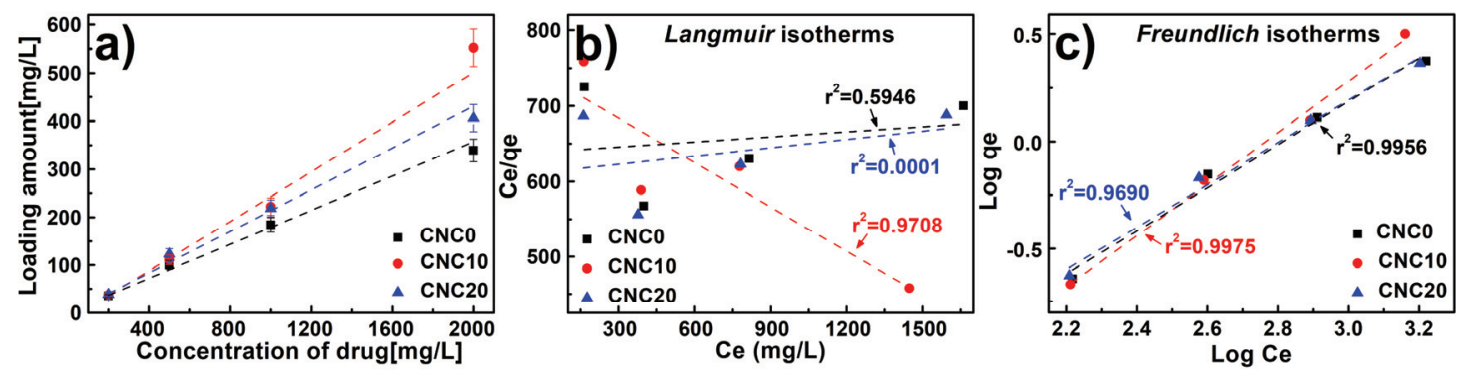

Fig. 6. Fitting of a)total loading drugs b)linear plots of Langmuir isotherms and c)linear plots of Freundlich isotherms over PVA/CNCs/GA hydrogels with varied CNCs content and their respective correlation coefficients. 
Preparation and Characterization of Cellulose Nanocrystals Reinforced Poly (vinyl alcohol)

Based Hydrogels for Drug Delivery System

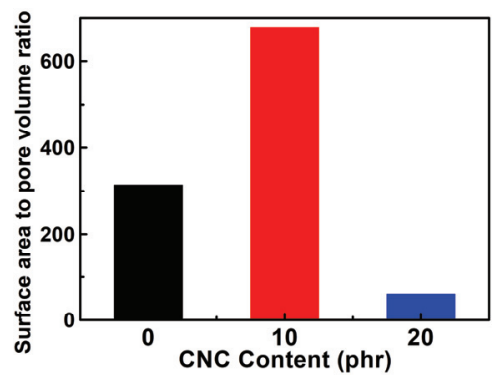

Fig. 7. Surface area to pore volume ratio $\left(\mathrm{m}^{2} \cdot \mathrm{g}^{-1} /\right.$ $\mathrm{cm}^{3} \cdot \mathrm{g}^{-1}$ ) of the PVA/CNCs/GA hydrogel systems with varied $\mathrm{CNCs}$ content.

surface area got increased by addition of CNC even though it has less space inside as explained previously with water content and swelling ratio. On the contrary, comparing $\mathrm{CNC} 0$ with $\mathrm{CNC} 20$, $\mathrm{CNC} 20$ had a larger inner surface area than $\mathrm{CNC} 0$, but showed a less amount of adsorption. As shown in FT-IR results, the drug loading action point of hydrogel increased due to free-OH on $\mathrm{CNCs}$ surface with the addition of CNCs.

When comparing the drug loading performance of the hydrogels to which $\mathrm{CNC} 10$ and $\mathrm{CNC} 20$ were applied, it was confirmed that the loading efficiency of CNC20 was reduced compared to that of $\mathrm{CNC10}$. It may be explained by a decrease of inner surface area and adsorption mechanism. To understand the mechanism of adsorption inside the hydrogels for drug loading, it was applied to Langmuir and Freundlich isotherm described in Section 2.3.5. The results are shown in Figs. 6b. and 6c. The correlation coefficients $\left(\mathrm{r}^{2}\right.$ : correlation coefficients) of $\mathrm{CNC}, \mathrm{CNC10}$, and CNC20 calculated by Langmuir isotherm were 0.5946 , 0.9708 , and 0.0001 . Also, it was calculated to be $0.9956,0.9975$, and 0.9690 by Freundlich isotherm, therefore, it was confirmed that Freundlich isotherm is more suitable for the salicylic acid loading mechanism of CNCs-based PVA hydrogels than Langmuir isotherm. Therefore, the drug ions, with the salicylic acid molecules on the inner interface of the hydrogels,
Table 3. The Freundlich isotherm constants for the loading drugs

\begin{tabular}{ccc}
\hline & $\mathrm{n}$ & $\mathrm{K}_{\mathrm{F}}$ \\
\hline \hline $\mathrm{CNC0}$ & 0.9530 & 0.0244 \\
$\mathrm{CNC10}$ & 1.2241 & 0.0497 \\
$\mathrm{CNC} 20$ & 1.0653 & 0.0287 \\
\hline
\end{tabular}

* n: Freundlich isotherm constant.

* $\mathrm{K}_{\mathrm{F}}$ : Freundlich constant.

were layered ina multi-molecule layer (Freundlich isotherm) instead of being bound as a mono molecular layer (Langmuir isotherm). It was confirmed that they were stacked in a multi-molecule layer due to electrical action that is on various pore interfaces inside and on interface between a drug ion and another, and differences in electrical strength such as radicals, van der Waals forces, etc. (Cho et al., 2013; Tilak et al., 2016; Li and Mooney, 2016). It shows that it needs enough space to load by forming a multi-molecular layer on the surface as a drug is loaded in a chemical and physical way on CNCs-based PVA hydrogels. To evaluate adsorption capacity, it can be presented in Table 3 with Freundlich constant $\mathrm{K}_{\mathrm{F}}$ from the equation (6) and experiment constant nfrom Freundlich isotherm. At $\mathrm{K}_{\mathrm{F}}$ and $\mathrm{n}$ which represent adsorption performance, CNC10 showed higher values than CNC20, confirming that $\mathrm{CNC} 10$ was a more favorable condition for drug loading. In conclusion, to increase drug loading amount by improving the mechanical strength on CNCs-based PVA hydrogels, a content of CNCs should be optimized and application of $\mathrm{CNC10}$ is more beneficial.

\subsection{Drug release properties}

A drug release behavior applied to the hydrogels has a significance in the light of an effective use of the drug. The drug release properties of CNCs-based PVA hydrogels were characterized and the results are presented in Fig. 8a. As expected by performance 

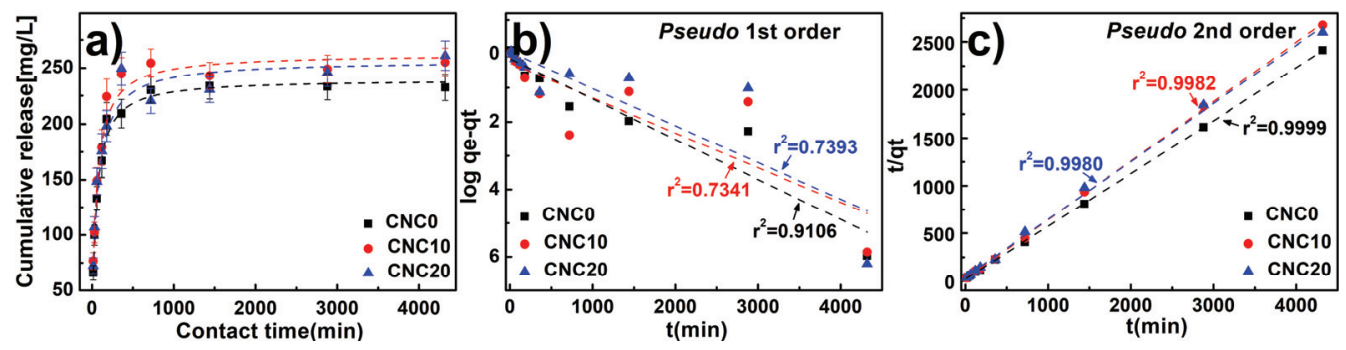

Fig. 8. Fitting of a)cumulative released drugs b)linear plots of pseudo $1^{\text {st }}$ order model released kinetics and c)linear plots of pseudo $2^{\text {nd }}$ order model released kinetics over PVA/CNCs/GA hydrogels with varied $\mathrm{CNCs}$ content and their respective correlation coefficients.

Table 4. The pseudo $1^{\text {st }}$ order model and pseudo $2^{\text {nd }}$ order model constants for the released drugs

\begin{tabular}{cccc}
\hline & Pseudo $1^{\text {st }}$ order model & Pseudo $2^{\text {nd }}$ order model \\
\hline \hline CNC0 & $\mathrm{k}_{1}=0.0028$ & $\mathrm{k}_{2}=0.0148$ & $\mathrm{~h}=0.0483$ \\
$\mathrm{CNC10}$ & $\mathrm{k}_{1}=0.0023$ & $\mathrm{k}_{2}=0.0106$ & $\mathrm{~h}=0.0263$ \\
$\mathrm{CNC20}$ & $\mathrm{k}_{1}=0.0025$ & $\mathrm{k}_{2}=0.0089$ & $\mathrm{~h}=0.0242$ \\
\hline
\end{tabular}

* $\mathrm{k}_{1}$ : Pseudo $1^{\text {st }}$ order model constant

* $\mathrm{k}_{2}$ : Pseudo $2^{\text {nd }}$ order model constant

* $\mathrm{h}$ : initial released rate

analysis of adsorption, the hydrogels applied with CNC10 having a high loading capacity reached to equilibrium at high temperatures with large release amounts. The results were described in Fig. 8b. and $8 \mathrm{c}$; all release data was applied to the pseudo $1^{\text {st }}$ order model and the pseudo $2^{\text {nd }}$ order model to evaluate release speed. By comparing $\mathrm{r}^{2}$ : correlation coefficient of a trend line, it was confirmed that the pseudo $2^{\text {nd }}$ order model was more suitable than the pseudo $1^{\text {st }}$ order model. The reaction speed constant $k_{2}$ and $h$, which means the initial release speed, were calculated for comparative analysis of drug release rate through the the pseudo $2^{\text {nd }}$ order model and the results were shown in Table 4. When CNCs were added, it showed that ' $h$ ' decreased, which represents the initial released speed of the prepared hydrogels. This demonstrates delayed release of drug by drug adsorption function of CNCs. When it was not added, most drugs were simply diffused by osmotic because they were mainly diluted instead of being combined on the inner surface of the hydrogels. On the other hand, it suggests that the CNCs-added hydrogels had a delayed release speed of the drug because of many acting points on CNCs surface and physical and chemical bonds among drug ions (Li et al., 2016). Accordingly, it was concluded that CNCs-added hydrogels had a positive effect on delayed release of the drug.

\section{CONCLUSION}

CNCs-based PVA hydrogels were prepared, and its physical, chemical and mechanical properties were investigated. Also, salicylic acid as a drug model was applied to investigate the adsorption and release properties of hydrophobic drugs, and the interaction between the drug and the hydrogels was evaluated using various dynamic models. The FT-IR results showed that inner PVA hydrogels with GA as a cross-linking- 
agent formed a 3D scaffold cross-linked network (semi-IPN), and it allowed a strong and dense 3D structure by adding CNCs. These characteristics of CNCs involved that water content and swelling ratio have decreased, andviscoelasticity has increased as the mechanical properties. In addition, from the analysis of drug loading behavior, Langmuir isotherm and Freundlich isotherm were applied, and it was found that Freundlich isotherm is more suitable than Langmuir isotherm. From this study, it has been loaded ina multi-molecular layer multiplied by physical and chemical bonds inside the hydrogels, not a mono-molecular layer of the drug. The addition of CNCs increased hydroxyl groups that did not involve with the formation of the 3D network structure, increasing drug loading amounts. Besides, $\mathrm{CNC} 10$ having a larger inner specific surface than $\mathrm{CNC} 20$ showed ahigher loading capacity. Also, the drug release properties analysis found the effect of delayed release of a drug and a high potential of crystalline nanocellulose $\mathrm{CNCs}$ as a core material of the delayed release drug delivery system.

\section{REFERENCES}

An, Q., Beh, C., Xiao, H. 2014. Preparation and characterization of thermo-sensitive poly(vinyl alcohol)-based hydrogel as drug carrier. Journal of Applied Polymer Science 131(1): 39720.

Cho, H., Baek, K., Jeon, J., Park, S., Suh, D., Park, Y. 2013. Removal characteristics of copper by marine macro-algae-derived chars. Chemical Engineering Journal 217: 205-211.

Gao, Y., Zhu, W., Liu, J., Di, D., Chang, D., Jiang, T., Wang, S. 2015. A geometric pore adsorption model for predicting the drug loading capacity of insoluble drugs in mesoporous carbon. International Journal of Pharmaceutics 485(1): 25-30.

Gwon, J., Cho, H., Chun, S., Lee, S., Wu, Q., Lee,
S. 2016. Physiochemical, optical and mechanical properties of poly(lactic acid) nanocomposites filled with toluene diisocyanate grafted cellulose nanocrystals. RSC Advances 6: 9438-9445.

Gwon, J., Cho, H., Lee, D., Choi, D., Lee, S., Wu, Q., Lee, S. 2018. Physicochemical and mechanical properties of polypropylene-cellulose nanocrystal nanocomposites: Effects of manufacturing process and chemical grafting. BioResources 13(1): 16191636.

Gwon, J., Lee, D., Cho, H., Lee, S. 2018. Preparation and characteristics of cellulose acetate based nanocomposites reinforced with cellulose nanocrystals (CNCs). Journal of the Korean Wood Science and Technology 46(5): 565-576.

Hendrawan, H., Khoerunnisa, F., Sonjaya, Y., Putri, A.D. 2019. Poly (vinyl alcohol)/glutaraldehyde/ Premna oblongifolia Merr extract hydrogel for controlled-release and water absorption application. In IOP Conference Series: Materials Science and Engineering; IOP Publishing: Bristol, UK. 012048.

Hoare, T.R., Kohane, D.S. 2008. Hydrogels in drug delivery: Progress and challenges. Polymer 49(8): 1993-2007.

Hyon, S., Cha, W., Ikada, Y. 1989. Preparation of transparent poly(vinyl alcohol) hydrogel. Polymer Bulletin 22(2): 119-122.

Khanjanzadeh, H., Park, B. 2020. Characterization of carboxylated cellulose nanocrystals from recycled fiberboard fibers using ammonium persulfate oxidation. Journal of the Korean Wood Science and Technology 48(2): 231-244.

Kim, H., Jegal, J., Kim, J., Lee, K., Lee, Y. 2003. Enantioselective permeation of $\alpha$-amino acid optical isomers through crosslinked sodium alginate membranes. Journal of Applied Polymer Science 89(11): 3046-3051.

Ladet, S., David, L., Domard, A. 2008. Multi-membrane hydrogels. Nature Letters 452: 76-79. 
Hyejung CHO $\cdot$ Won-Jae YOO $\cdot$ Jinsoo AHN $\cdot$ Sang-Jin CHUN $\cdot$ Sun-Young LEE $\cdot$ Jaegyoung GWON

Li, J., Mooney, D.J. 2016. Designing hydrogels for controlled drug delivery. Nature Reviews Materials 1: 16071 .

Lin, C.C., Metters, A.T. 2006. Hydrogels in controlled release formulations: Network design and mathematical modeling. Advanced Drug Delivery Reviews 58(12): 1379-1408.

Mansur, H.S., Sadahira, C.M., Souza, A.N., Mansur, A.A. 2008. FTIR spectroscopy characterization of poly (vinyl alcohol) hydrogel with different hydrolysis degree and chemically crosslinked with glutaraldehyde. Materials Science and Engineering C 28: 539-548.

Marin, E., Rojas, J. 2015. Preparation and characterization of crosslinked poly (VINYL) alcohol films with waterproof properties. International Journal of Pharmacy and Pharmaceutical Sciences 7(3): 242-248.

Masruchin, N., Park, B.D., Causin, V. 2015. Influence of sonication treatment on supramolecular cellulose microfibril-based hydrogels induced by ionic interaction. Journal of Industrial and Engineering Chemistry 29(25): 265-272.

McKenzie, M., Betts, D., Suh, A., Bui, K., Kim, L.D., Cho, H. 2015. Hydrogel-based drug delivery systems for poorly water-soluble drugs. Molecules 20(11): 20397-20408.

Pal, K., Banthia, A.K., Majumdar D.K. 2007. Preparation and characterization of polyvinyl alcoholgelatin hydrogel membranes for biomedical applications. An Official Journal of the American Association of Pharmaceutical Scientists 8(1): E142-E146.

Reis, E.F.D., Campos, F.S., Lage, A.P., Leite, R.C., Heneine, L.G., Vasconcelos, W.L., Mansur, H.S. 2006. Synthesis and characterization of poly (vinyl alcohol) hydrogels and hybrids for rMPB70 protein adsorption. Materials Research 9(2): 185-191.

Rivas, C.J.M., Tarhini, M., Badri, W., Miladi, K.,
Greige-Gerges, H., Nazari, Q. A., Rodriguez, S.A.G., Roman, R.A., Fessi, H., Elaissari, A. 2017. Nanoprecipitation process: From encapsulation to drug delivery. International Journal of Pharmaceutics 532(1): 66-81.

Tanpichai, S., Oksman, K. 2016. Cross-linked nanocomposite hydrogels based on cellulose nanocrystals and PVA: Mechanical properties and creep recovery. Composites Part A: Applied Science and Manufacturing 88: 226-233.

Thangprasert, A., Tansakul, C., Thuaksubun, N., Meesane, J. 2019. Mimicked hybrid hydrogel based on gelatin/PVA for tissue engineering in subchondral bone interface for osteoarthritis surgery. Materials and Design, 183: 108113.

Mezger, T. 2015. Applied rheology: With Joe flow on rheology road. Anton Paar.

Tilak, A., Thakur, R.N., Sharma, R., Verma, M., Gupta, A.K. 2016. Study of adsorption of drug and calculation of Freundlich adsorption isotherm. International Journal of Pharmaceutical and Biological Science Archive 4(4): 01-05.

Valle, L.J.D,. Diaz, A., Puiggali, J. 2017. Hydrogels for biomedical applications: cellulose, chitosan, and protein/peptide derivatives. Gels 3(3): 27.

Wang, Q., Mynar, J.L., Yoshida, M., Lee, E., Lee, M., Okuro, K., Kinbara, K., Aida. T. 21, January 2010. High-water-content mouldable hydrogels by mixing clay and a dendritic molecular binder. Nature Letters 463: 339-343.

Xiao, C., Zhou, G. 2003. Synthesis and properties of degradable poly(vinyl alcohol) hydrogel. Polymer Degradation and Stability 81(2): 297-301.

Yeom, C., Lee, K. 1996. Pervaporation separation of water-acetic acid mixtures through poly (vinyl alcohol) membranes crosslinked with glutaraldehyde. Journal of Membrane Science 109(2): 257-265.

Yue, Y., Han, J., Han, G., French, A.D., Qi, Y., Wu, Q. 2016. Cellulose nanofibers reinforced sodium 


\section{Preparation and Characterization of Cellulose Nanocrystals Reinforced Poly (vinyl alcohol)}

Based Hydrogels for Drug Delivery System

alginate-polyvinyl alcohol hydrogels: Core-shell structure formation and property characterization. Carbohydrate Polymers 147: 155-164.

Zaini, L., Febrianto, F., Wistara, I., Marwanto, N., Maulana, M., Lee, S., Kim, N., 2019. Effect of ammonium persulfate concentration on characteristics of cellulose nanocrystals from oil palm frond. Journal of the Korean Wood Science and Technology 47(5): 597-606.
Zawko, S.A., Truong, Q., Schmidt, C.E. 2008. Drugbinding hydrogels of hyaluronic acid functionalized with $\beta$-cyclodextrin. Journal of Biomedical Materials Research Part A 87(4): 1044-1052.

Zhou, Y., Zhang, L., Cheng, Z. 2015. Removal of organic pollutants from aqueous solution using agricultural wastes: A review. Journal of Molecular Liquids 212: 739-762. 


\title{
APPENDIX
}

\author{
(Korean Version)
}

\section{약물 전달 시스템 적용을 위한 셀룰로오스 나노크리스탈(CNCs) 강화 Poly(vinyl alcohol) 기반 하이드로겔의 제조 및 특성}

초록 : 기존 연질 구조의 하이드로겔은 낮은 기계적 강도로 인하여 생의학 분야에서 응용이 제한된다. 본 연구에서는 이러한 단점을 극복하기 위해서 폴리비닐알코올(PVA: poly(vinyl alcohol))기반 하이드로겔에 셀룰로오스 나노크리스탈(CNCs)을 첨 가하여 $\mathrm{CNCs}$ 가 기계적 특성 및 약물전달 효율에 미치는 영향을 확인하였다. 제조된 하이드로겔은 FT-IR 분석으로 아세탈 및 알데히드 결합으로 가교결합된 망상구조(semi-IPN: semi-interpenetrating polymer network)로 합성된 것이 확인되었다. $\mathrm{CNCs}$ 함량이 증가될수록 수분 흡수 및 팽윤도가 감소했으며, 점탄성은 증가하였다. 또한 CNCs의 첨가는 약물 로딩량의 증가와 약물 방출량의 지속성을 향상시켰다. 이러한 결과는 $\mathrm{CNCs}$ 를 하이드로겔에 첨가하는 것이 하이드로겔의 약물전달 효율성 및 기계적 특성을 개선시키는 좋은 대안이 될 수 있음을 보여주었다.

\section{1. 서 론}

약물 전달 시스템(DDS, Drug Delivery System)이란 의약품의 부작용을 최소화하면서 효능을 극대화시켜 필요한 양의 약물을 효율적으로 전달하는 투여 경로와 약의 형태로 정의되는데(Rivas et al., 2017), 이는 보다 정교해진 약물전달시스템을 통하여 약물 유효성의 시·공간적 제어로 안정성 및 효율성을 높여야 한다.

다량의 물을 흡수한 상태일 때 생체 조직과 유사한 거동을 보이는 하이드로겔은 물리 화학적 가교결합을 통한 3차원 구조체를 형성하고 있기 때문에 생체적합성이 높아 약물전달시스템 적용에 유리하다(An et al., 2017; Valle et al., 2017; Tanpichai and Oksman, 2016; Xiao and Zhou, 2013; Li and Mooney, 2016; Hyon et al., 1989; Pal et al., 2016). 하지만 하이드로겔의 낮은 인장강도는 구조의 지지력이 있어야 하는 부분에서 응용을 제한하고, 목표로 하는 지점에서 조기 용해 과정을 거쳐 빠른 시간에 분해된다.

또한, 대부분의 저분자 약물이 갖는 소수성으로 인하여 높은 함수율과 다공성 구조인 하이드로겔에 약물의 탑재가 어렵고 삼투압 으로 인한 빠른 방출은 하이드로겔을 산업적으로 활용하고자 할 때 단점으로 지적되고 있다(Rivas et al., 2017; McKenzie et al., 2015). 이러한 단점을 극복하기 위해 하이드로겔을 몰드에서 성형하는 것 뿐만 아니라 다양한 형태로 결합하여 기계적 강도를 높이거나(Wang et al., 2010; Hyon et al., 1989) 다층 구조를 갖는 멤브레인 형태의 하이드로겔을 제조하여 내부 공동(cavity)에 소수성 화합물 결합을 용이하게 유도한 연구(Ladet et al., 2008; Lin et al., 2006; Zawko et al., 2008)가 진행된 바 있다.

제조된 하이드로겔의 기계적 특성을 향상시키고 소수성 약물의 탑재 효율 향상과 지연 방출을 위하여 자연에 널리 분포하고 있는 셀룰로오스를 이용하여 제조된 유기 계열 나노 소재인 셀룰로오스 나노크리스탈(CNCs)을 생분해 가능한 PVA(Poly(vinyl alcohol)) 기반 하이드로겔에 적용하였다. 산가수분해로 제조되는 CNCs의 경우 주로 황산을 이용하여 제조되며 5-70 nm의 두께와 $300 \mathrm{~nm}$ 이하의 길이를 가지고 있어 부피대비 표면적이 넓다. 같은 나노셀룰로오스 계열의 셀룰로오스 나노섬유(cellulose nanofiber, $\mathrm{CNF})$ 에 비해 결정화도가 높고 표면의 많은 수산기(-OH)로 인해 반응성이 높아 손쉽게 화학적 개질이 가능하여 고분자 복합소재 분야에서 친환경 강화제(reinforcement)로 각광 받고 있다(Gwon et al., 2016; Gwon et al., 2018; Khanjanzadeh and Park 2020; Zaini et al., 2019). 특히 넓은 비표면적과 수많은 수산기로 인해 다량의 물을 흡수할 수 있는 능력과 황산 처리로 인한 표면의 황산염(surfate, $\mathrm{SO}_{4}^{2-}$ )은 소수성 약물의 흡착과 지연방출 효율을 극대화할 수 있을 것으로 기대된다. 따라서, $\mathrm{CNCs}$ 의 적용은 하이드로겔의 기계적 특성 향상과 약물전달 효율 향상 측면에서 하나의 좋은 해결책이 될 수 있다.

본 연구에서는 글루타알데하이드(glutaraldehyde, GA)를 가교제로 사용한 PVA 하이드로겔 시스템에 CNCs를 적용하였으며, 소수성 약물로 살리실산(salicylic acid, SA)을 도입하고 약물 흡착 및 방출 거동을 살펴보았다. 하이드로겔 구조 특성을 확인하기 위하여 적외선 분광기 분석, 함수율, 팽윤도, 비표면적 분석, 주사전자현미경 분석 및 점탄성 특성을 평가하였고, 하이드로겔과 약물의 상호 반응은 Langmuir, Freundlich 흡착 모델을 적용하였으며, 방출 거동은 Lagergren's pseudo $1^{\text {st }}$ order model 및 Ho's pseudo $2^{\text {nd }}$ order model을 적용하여 확인하였다. 
Preparation and Characterization of Cellulose Nanocrystals Reinforced Poly (vinyl alcohol) Based Hydrogels for Drug Delivery System

\section{2. 재료 및 방법}

\section{1. 공시재료}

분자량이 $61000 \mathrm{Da}$ 인 폴리비닐알코올(Poly(vinyl alcohol), PVA, Mowiol ${ }^{\circledR} 10-98$, Sigma-aldrich)을 기반으로 결정형 고분자 인 셀룰로오스 나노크리스탈(CNCs)을 첨가하고 글루타알데하이드(glutaraldehyde, GA, Sigma-aldrich)를 가교제로 사용하여 하이드로겔을 제조하였다. 본 연구에서 사용된 CNCs는 Nippon Paper Chemicals Co., Ltd.(Tokyo, Japan)에서 셀룰로오스(KC Flock W-50, 평균 사이즈: $45 \mu \mathrm{m}$ ) 파우더를 구매하여 선행 연구(Gwon et al., 2016; Gwon et al., 2018)와 동일한 방식으로 $64 \mathrm{wt} . \%$ 황산 $\left(\mathrm{H}_{2} \mathrm{SO}_{4}\right.$, Junsei, Japan)을 사용하여 $45{ }^{\circ} \mathrm{C}$ 조건에서 20 분동안 산 가수분해 후 원심분리하여 상등액이 중성이 될 때까지 수세하여 제조하였다. 증류수를 용매로 사용된 $\mathrm{CNCs} / \mathrm{PVA}$ 현탁액은 $\mathrm{pH} 4.0 \pm 0.2$ 로 제조되어지는데 $\mathrm{GA}$ 를 첨가하여 $0.5 \mathrm{~N} \mathrm{HCl}(0.5 \mathrm{~N}-H y d r o c h l o r i c ~ a c i d ~ s t a n d a r d ~ s o l u t i o n$, Daejung Chemicals \& Metals Co., Ltd, Korea)을 촉매로 사용하여 $\mathrm{pH} 2.0 \pm 0.02$ 까지 결합 반응을 유도하여 하이드로겔을 제조하였다. 제조된 하이드로겔은 소수성 저분자 약물 중 하나인 살리실 산(salicylic acid, $\geq 99.0 \%$, Sigma-aldrich)을 이용하여 약물 로딩 및 방출 특성을 확인하였다.

\section{2. $\mathrm{CNCs}$ 기반 $\mathrm{PVA}$ 하이드로겔 제조}

현탁액은 $200 \mathrm{~mL}$ 증류수에 $5 \mathrm{wt} . \% \mathrm{PVA}$ 를 $70{ }^{\circ} \mathrm{C}$ 로 중탕하여 녹인 후 $\mathrm{PVA}$ 대비 $\mathrm{CNCs}$ 를 건조중량 $0,10,20 \mathrm{phr}$ 조건으로 첨가하여 $200 \mathrm{rpm}$ 으로 6시간 동안 교반한다. $\mathrm{CNCs}$ 첨가량에 따라 $\mathrm{CNC} 0, \mathrm{CNC} 10, \mathrm{CNC} 20$ 이라 표시하였다. CNCs 함량이 다른 각각의 현탁액을 충분히 교반하여 $\mathrm{CNCs}$ 가 고르게 분산된 $\mathrm{CNCs} / \mathrm{PVA}$ 현탁액을 제조하여 상온까지 데시게이터 안에서 방냉하였다. $\mathrm{CNCs} / \mathrm{PVA}$ 현탁액에 PVA대비 $5 \mathrm{phr}$ (part per hundred resin) 조건의 $\mathrm{GA}$ 를 점적방식으로 첨가하여 5 분간 교반한다. $0.5 \mathrm{~N} \mathrm{HCl}$ 를 첨가하여 $\mathrm{pH}$ 를 $2.0 \pm 0.02$ 까지 조절한 후, 직경 $20 \mathrm{~mm}$ 높이 $8 \mathrm{~mm}$ 알루미늄 몰드에 넣어 상온에서 48 시간 경화시켰다. 제조된 하이드로겔 표면이 중성이 될 때까지 증류수로 세척하여 합성 반응 후 표면에 남은 잔여 물질인 미반응된 가교제 및 $\mathrm{pH}$ 조절에 사용된 $0.5 \mathrm{~N} \mathrm{HCl}$ 등을 제거하고, 세척이 완료된 시편은 $5^{\circ} \mathrm{C}$ 챔버에 보관하여 사용하였다. 하이드로겔의 제조는 Table 1과 같은 조성으로 제조되었다. 제조된 하이드로겔은 Fig. 1과 같이 CNCs 함량이 증가할수록 투명도가 감소되는 것을 확인할 수 있었으며, 색상 변화는 발생되지 않았다.

\section{3. $\mathrm{CNCs}$ 기반 PVA하이드로겔 특성 분석}

2.3.1. 비표면적 및 주사전자현미경 이미지 분석

제조된 하이드로겔을 액체 질소로 급속 냉동한 뒤 $-60{ }^{\circ} \mathrm{C}$ 냉동고에 보관 후 동결건조기(FDU-1200, Eyela, Tokyo, Japan)를 이용하여 건조된 시편을 제조하였다. 동결 건조된 시편을 $20^{\circ} \mathrm{C}$ 조건에서 30 분간 degassing하여 잔여 수분을 없앤 후 액체

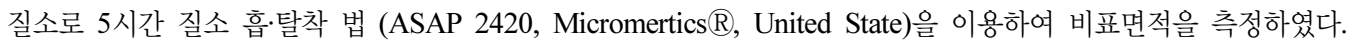

동결 건조된 시편 표면을 $4 \mathrm{~mA}$ 로 200초 동안 스퍼터 방식으로 $2 \mathrm{~nm}$ 금박막(Ion-Coater(KIC-IA), Coxem, Korea)을 입히고, FE-SEM(Coxem-30, Coxem, Korea) 측정하여 CNCs 함량 차이에 따라 달라진 하이드로겔 이미지를 얻었다.

\subsection{2. 화학적 관능기 분석}

적외선 분광기인 FT-IR (Nicolet iS10 FT-IR Spectrometer, Thermo Scientific, United State)을 이용하여 약물이 로딩된 하이드로겔과 로딩되지 않은 하이드로겔의 계면 특성을 확인하였다. 모든 샘플은 표면 세척 후 $70{ }^{\circ} \mathrm{C}$ 챔버에서 24 시간 건조하여 사용하였다. 단, 약물 로딩된 하이드로겔은 세척 전 $37{ }^{\circ} \mathrm{C}$ 챔버에서 48 시간 약물에 침지시킨 후, 하이드로겔 표면이 중성이 될 때까지 증류수로 세척하여 표면에 남은 잔여 물질을 제거하였다. FT-IR 분석은 ATR mode, scan range $400 ~ 4000 \mathrm{~cm}^{-1}$, 32 total scan, $8 \mathrm{~cm}^{-1}$ resolution 조건으로 분석하였다.

2.3.3. $\mathrm{CNCs}$ 기반 $\mathrm{PVA}$ 하이드로겔의 함수율 및 팽윤도 테스트

$\mathrm{CNCs}$ 기반 PVA하이드로겔의 함수율을 확인하고자 충분히 세척된 하이드로겔을 $70{ }^{\circ} \mathrm{C}$ 챔버에 넣고 24 시간 완전 건조 후 저울(HR-250AZ, A\&D Co., Ltd., Korea)을 이용하여 건조 전후 중량 변화량을 측정하였다. 중량 측정시 $\pm(0.1 \%)$ 오차 범위의 중량을 3 반복하여 확정하였다.

$$
\begin{aligned}
& \text { Weight remaining }(\%)=\left(\mathrm{W}_{\mathrm{i}}-\mathrm{W}_{\mathrm{d}}\right) / \mathrm{W}_{\mathrm{i}} \times 100 \\
& \qquad \mathrm{~W}_{\mathrm{i}} \text { : 초기 무게 } \\
& \mathrm{W}_{\mathrm{d}} \text { : 건조 후의 무게 }
\end{aligned}
$$


하이드로겔의 팽윤 특성을 확인하고자 $70{ }^{\circ} \mathrm{C}$ 챔버에서 12 시간 건조한 하이드로겔을 $37{ }^{\circ} \mathrm{C}$ 증류수에 넣어 초기 질량 대비 시간에 따른 중량에 따른 팽윤도를 확인하였다. 중량 측정시 $\pm(0.1 \%)$ 오차 범위의 중량을 3 반복하여 확정하였다.

$$
\begin{gathered}
\text { Swelling ratio }(\%)=\left(\mathrm{W}_{\mathrm{s}}-\mathrm{W}_{\mathrm{d}}\right) / \mathrm{W}_{\mathrm{d}} \times 100 \\
\mathrm{~W}_{\mathrm{d}} \text { : 건조 후의 무게 } \\
\mathrm{W}_{\mathrm{s}} \text { : 팽윤된 무게 }
\end{gathered}
$$

2.3.4. CNCs기반 $\mathrm{PVA}$ 하이드로겔의 기계적 특성

$\mathrm{CNCs}$ 함량에 따라 하이드로겔의 기계적 특성 변화를 확인하고자 $\mathrm{CNCs}$ 기반 PVA하이드로겔의 저장 탄성률 및 손실 탄성률 을 parallel 및 peltier plate를 이용하여 DHR3 rheometer (TA instruments, US)로 측정하였다. 분석 조건은 온도 $25^{\circ} \mathrm{C}$, strain $10 \%$, axial force $0.5 \mu \mathrm{N}$, frequency sweep의 경우 0.1 100 radius/s 범위에서 측정하였다.

저장 탄성률 및 손실 탄성률은 다음과 같은 식의 값으로 도출하였다(Wang et al., 2010).

$$
\begin{gathered}
\text { Storage Modulus, } G^{\prime}(\mathrm{Pa})=\frac{\sigma}{\epsilon} \cdot \cos \theta \quad \text { Loss Modulus, } \mathrm{G}^{\prime \prime}(\mathrm{Pa})=\frac{\sigma}{\epsilon} \cdot \sin \theta \\
\sigma: \text { Shear stress } \\
\mathcal{E}: \text { Shear strain }
\end{gathered}
$$

2.3.5. CNCs기반 PVA하이드로겔의 약물 로딩 및 방출

빠른 방출 및 로딩이 곤란한 소수성 저분자 약물에 대한 연구를 하고자 소수성 저분자 약물의 하나인 살리실산을 사용하였다. 로딩 실험을 위하여 $200,500,1000,2000 \mathrm{mg} / \mathrm{L}$ 각각 다른 농도의 약물에 $37{ }^{\circ} \mathrm{C}$ 챔버 안에서 48 시간 동안 증류수에 팽윤된 상태의 직경 $20 \pm 2 \mathrm{~mm}$, 높이 $8 \pm 2 \mathrm{~mm}$, 중량 $1.45 \pm 0.1 \mathrm{~g}$ 하이드로겔을 함침시켜 확인하였다. 로딩된 약물의 양은 HPLC (High Performance Liquid Chromatography, 1260 Series, Agilent)를 이용하여 측정하였다.

$\mathrm{CNCs}$ 기반 PVA하이드로겔 단위 중량당 로딩된 약물의 양을 분석하기 위하여 다음과 같이 계산하였다.

$$
\mathrm{q}_{\mathrm{e}}=\left(\mathrm{C}_{\mathrm{i}}-\mathrm{C}_{\mathrm{e}}\right) \times \mathrm{V} / 1000 \mathrm{w}
$$

$\mathrm{V}$ : 약물이 들어있는 용액의 부피 $(\mathrm{mL})$

$\mathrm{w}$ : 하이드로겔의 중량 $(\mathrm{g})$

$\mathrm{C}_{\mathrm{i}}$ : 초기 약물의 농도 $(\mathrm{mg} / \mathrm{L})$

$\mathrm{C}_{\mathrm{e}}$ : 평형 구간의 약물의 농도 $(\mathrm{mg} / \mathrm{L})$

$\mathrm{q}_{\mathrm{e}}$ : 하이드로겔 단위 중량당 약물이 로딩되어 평형 구간의 농도 $(\mathrm{mg} / \mathrm{g})$

함침법에 의해 약물이 로딩된 하이드로겔을 약물시스템에 적용하기 위한 공정 변수를 확보하고자 흡착 등온모델을 이용하여 하이드로겔 계면과 약물의 로딩의 모습을 예측하였다. 주로 화학적 결합에서 많이 보여주는 단일 계면에 단분자층으로 결합이 이루어지는 Langmuir isotherm과 물리적 흡착으로 불균일 계면에 약물이 다분자층으로 결합되는 Freundlich isotherm을 이용하 여 하이드로겔과 약물의 계면 반응을 확인하였다.(Cho et al., 2013)

Langmuir isotherm은 다음과 같다.

$$
q_{e}=\frac{q_{\max } b C_{e}}{1+b C_{e}} \text { 선형화하면, } \frac{C_{e}}{q_{e}}=\frac{1}{b \cdot q_{\max }}+\frac{C_{e}}{q_{\max }}
$$

$q_{\mathrm{e}}$ : 하이드로겔 단위 중량당 약물이 로딩되어 평형 구간의 농도 $(\mathrm{mg} / \mathrm{g})$

$C_{\mathrm{e}}$ : 평형 구간의 약물의 농도 $(\mathrm{mg} / \mathrm{L})$

$q_{\max }$ : 하이드로겔 단위 중량당 약물이 로딩될 수 있는 최대량 $(\mathrm{mg})$

$b$ : Langmuir 흡착상수

Freundlich isotherm은 다음과 같다.

$$
q_{e}=K_{F} C_{e}^{1 / n} \text { 선형화하면, } \log q_{e}=\log K_{F}+\frac{1}{n} \log C_{e}
$$

$q_{\mathrm{e}}$ : 하이드로겔 단위 중량당 약물이 로딩되어 평형 구간의 농도 $(\mathrm{mg} / \mathrm{g})$ 
Preparation and Characterization of Cellulose Nanocrystals Reinforced Poly (vinyl alcohol) Based Hydrogels for Drug Delivery System

\author{
$C_{\mathrm{e}}$ : 평형 구간의 약물의 농도 $(\mathrm{mg} / \mathrm{L})$ \\ $K_{\mathrm{F}}$ : Freundlich 흡착상수 \\ $n$ : Freundlich isotherm에서 유도된 흡착상수
}

약물의 방출 거동 확인은 하이드로겔을 약물 농도가 $2000 \mathrm{mg} / \mathrm{L}$ 인 조건에서 48 시간 노출시켜 약물이 충분히 로딩된 후, 약물이 로딩되어있는 직경 $20 \pm 2 \varnothing$, 높이 $8 \pm 2 \mathrm{~mm}, 1.45 \pm 0.1 \mathrm{~g}$ 하이드로겔을 체온과 유사한 $37^{\circ} \mathrm{C}$ 챔버내에서 증류수 $10 \mathrm{~mL}$ 에 완전히 넣어 $50 \mathrm{rpm}$ 조건으로 교반하여 약물이 충분히 방출될 수 있는 환경을 제공하였다. 시간에 따라 단위 중량당 방출되는 약물의 농도를 HPLC (High Performance Liquid Chromatography, 1260 Series, Agilent, United State)를 이용하여 측정하였다.

약물이 로딩된 $\mathrm{CNCs}$ 기반 $\mathrm{PVA}$ 하이드로겔에서 약물이 방출되는 특성을 시간에 따라 동력학적으로 해석하고자 pseudo $1^{\mathrm{st}}$ order model, pseudo $2^{\text {nd }}$ order model을 이용하였다.

Pseudo $1^{\text {st }}$ order equation 다음과 같다

$$
\frac{d q_{t}}{d_{t}}=k_{1}\left(q_{e}-q_{t}\right) \text { 선형화하면, } \log \frac{q_{e}}{\left(q_{e}-q_{t}\right)}=\frac{k_{1} t}{2.303}
$$

$q_{\mathrm{e}}$ : 평형을 이루는 동안 방출된 양 $(\mathrm{mg} / \mathrm{g})$

$q_{\mathrm{t}}$ : 단위 시간에 방출된 양 $(\mathrm{mg} / \mathrm{g})$

$k_{1}$ : pseudo 1 차 모델에서의 속도상수

$t$ : Reaction time

Pseudo $2^{\text {nd }}$ order equation 다음과 같다

$$
\begin{aligned}
& \frac{d q_{t}}{d_{t}}=k_{2}\left(q_{e}-q_{t}\right)^{2} \text { 선형화하면, } \frac{1}{q_{e}-q_{t}}=\frac{1}{q_{e}}+k_{2} t \\
& q_{\mathrm{e}}: \text { 평형을 이루는 동안 방출된 양 }(\mathrm{mg} / \mathrm{g}) \\
& q_{\mathrm{t}} \text { : 단위 시간에 방출된 양 }(\mathrm{mg} / \mathrm{g}) \\
& k_{2}: p s e u d o \text { 차 모델에서의 속도상수 } \\
& t: \text { Reaction time }
\end{aligned}
$$

추가적으로 pseudo $2^{\text {nd }}$ order equation 따라 $h=k_{2} q_{e}^{2}$ 도출하여 초기 방출속도 값(h)을 얻었다(Cho et al., 2013).

살리실산의 분석은 $\mathrm{HPLC}$ 를 이용하여 Table 2 와 같은 조건으로 분석하였다.

\title{
3. 결과 및 고찰
}

3.1. 화학 및 형태학적 특성

제조된 CNCs기반 PVA하이드로겔과 약물이 탑재된 하이드로겔의 FT-IR 측정 결과를 Fig. 2에 나타내었다. 예상할 수 있듯이 $\mathrm{CNCs}$ 첨가로 인해 free-OH group을 나타내는 $3000-3600 \mathrm{~cm}^{-1}$ 영역의 피크 강도가 상승한 것을 확인할 수 있으며, 2930 $\mathrm{cm}^{-1}$ 범위의 -CH stretching vibration band, 알데하이드 그룹에서 보이는 피크들인 2750 2850 cm-1 범위의 C-H stretching band, 1720 1740 $\mathrm{cm}^{-1}$ 범위의 $\mathrm{C}=\mathrm{O}$ vibration band가 나타나는 것을 확인할 수 있었다(Reis et al., 2006; Mansur et al., 2008; Hendrawan et al., 2019; Marin and Rojas, 2015). 특히, 1720 1740 cm-1 범위에서 약물이 로딩되지 않은 하이드로겔에서는 가교제의 미반응 $\mathrm{C}=\mathrm{O}$ 그룹들이 나타났으나 약물과의 반응으로 약물이 로딩된 하이드로겔에서는 $1700 \mathrm{~cm}^{-1}$ 근처에서 피크가 약해진 것을 확인할 수 있었다(Thangprasert et al., 2019). 또한 GA의 알데히드 그룹(-CHO)과 PVA와 CNCs의 수산기(-OH)의 가교 결합에 의해 형성되는 아세탈과 에테르 그룹들에 대한 피크들이 $1371 \mathrm{~cm}^{-1}, 1250 \mathrm{~cm}^{-1}, 950 \mathrm{~cm}^{-1}$ 영역에서 나타나는 것을 확인할 수 있었다(Yue et al., 2016; Yeom and Lee, 1996; Kim et al., 2003). 알데하이드 그룹의 존재는 GA의 두 개의 작용기 중 하나만 결합된 불완전한 가교 결합(hemi-acetal)이 존재한다는 것을 의미한다. 헤미 아세탈(hemi-acetal) 그룹이 존재 하지만 아세탈과 에테르 그룹들이 형성된 것을 통해 고분자 한 종류를 사용한 본 연구에서 제조된 하이드로겔의 경우, 3 차원으로 가교결합된 망상 구조(semi-IPN)를 형성한 것을 알 수 있다(Yue et al., 2016).

하이드로겔의 3 차원 망상구조를 확인을 위해 주사전자현미경(SEM, scanning electron microscopy)을 측정하고 이를 Fig. 3 에서 보여주었다. 앞서 설명한 것처럼 $\mathrm{PVA}, \mathrm{CNCs}$ 의 수산기와 $\mathrm{GA}$ 의 사이의 가교결합으로 인해 인접한(interconnected) 3 차원 기공 구조를 가지고 있는 것을 확인할 수 있었으며, $\mathrm{CNCs}$ 함량이 증가될수록 기공 크기가 증가되는 것을 확인할 수 있었다. 
Hyejung $\mathrm{CHO} \cdot$ Won-Jae YOO $\cdot$ Jinsoo AHN $\cdot$ Sang-Jin CHUN $\cdot$ Sun-Young LEE $\cdot$ Jaegyoung GWON

\section{2. 함수율 및 팽윤도}

하이드로겔은 수분 흡수에 의한 고분자 사슬의 팽창을 통한 방출 제어 장치라고 볼 수 있으며 이러한 하이드로겔의 거동은 약물 확산 특히, 방출 거동에 영향을 준다. 방출 속도는 겔 네트워크를 통해 움직이는 용매 분자들의 능력에 의해 결정되며, 고분자 사슬 사이로의 확산과 사슬의 응력완화(relaxation)로 겔이 팽윤하는 동안 구조가 형태학적 변화를 일으킨다(Mansur et al., 2008). 그러므로 함수율과 팽윤도 특성들의 이해는 추후 본 연구에서 진행된 살리실산 약물방출 거동을 이해하는데 있어서 중요하다. 본 연구에서 제조된 하이드로겔의 수분에 의한 특성 변화를 관찰하기 위해 함수율(water content)과 팽윤도 (swelling ratio)를 평가하고 이에 대한 결과는 Fig. 4에 나타내었다. 함수율의 경우 CNCs 함량이 0, 10, 20 phr로 증가할수록 $91.2,90.0,89.4 \%$ 로 나타났으며 팽윤도의 경우, $306,290,272 \%$ 로 각각 나타났다. 주목할 점은 함수율과 팽윤도가 $\mathrm{CNCs}$ 함량이 증가할수록 다소 감소하는 경향이다. 단순히 표면 친밀도(affinity) 관점에서 상기 거동을 분석하면, Fig. 2에서 확인 하였듯이 CNCs 첨가로 인해 친수성의 free-OH 작용기가 많아지는 것이 확인되고 이로 인해 수분 흡수가 많아져야 한다. 하지만 예상과 다르게 함수율이 CNCs 함량이 증가할수록 감소하였다. 이는 팽윤도 감소를 통해 설명될 수 있다. 팽윤도 감소는 하이드로겔 내부 공간의 공간적 제약이 작용한다고 볼 수 있다. 양용매(good solvent)와 혼합된 고분자의 경우 사슬 꼬임 (entanglement)이 풀어지고 늘어나면서 사슬의 움직임이 자유로워지고 그 사이 공간에 많은 양의 용매 분자가 들어가게 된다. 이로 인해 사슬이 차지하는 자유 공간이 커지게 되고 고분자 사슬 사이에 결정화도가 높은 단단한 입자가 삽입될 경우 이러한 사슬의 움직임이 저하되어 이로 인해 사슬의 자유도는 감소한다. 특히, 나노셀룰로오스와 PVA 사이의 유사한 표면 특성은 이 둘의 결합력을 향상시키며, 제조된 하이드로겔의 내부 구조는 빽빽하고 압축된 네트워크 구조를 가질 수 있다(Masruchin et al., 2015). 따라서, 함수율과 팽윤도의 감소는 CNCs 첨가에 의해 PVA 사슬 움직임의 억제 역할에 의한 현상으로 판단되었다. 약물전달 측면에서 하이드로겔은 많은 양의 수분을 함유할 수 있는 능력이 높을수록 하이드로겔 내부로 많은 양의 약물을 저장할 수 있다(Hoare and Kohane, 2008). 나노셀룰로오스의 첨가는 표면의 많은 free-OH의 영향으로 초기 수분 흡수율을 빠르게 하는 경향은 보이지만(Masruchin et al., 2015), 하이드로겔의 부피 증가에 의한 약물 탑재(loading) 향상 능력에는 긍정적인 영향을 미치지 않은 것으로 보여졌다.

\section{3. 기계적 특성}

$\mathrm{CNCs}$ 가 첨가된 PVA의 하이드로겔들의 기계적 특성을 Fig. 5에 나타낸 것처럼 저장 탄성률(storage modulus, G')과 손실 탄성률(loss modulus, $\left.\mathrm{G}^{\prime \prime}\right)$ 의 점탄성 특성(vicoelastic property) 결과 분석을 통해 확인하였다. $\omega($ angular frequency)변화에 따라 $\mathrm{G}^{\prime}$ 이 $\mathrm{G}^{\prime \prime}$ 에 비해 높은 값을 유지하는 것을 확인할 수 있으며, 이를 통해 본 연구에서 제조된 하이드로겔이 단단한 고체 거동을 보인다고 할 수 있다(Yue et al., 2016). 이는 3.1.절에서 설명한 바와 같이 아세탈, 에테르, 수소 결합들과 PVA 고분자 사슬의 꼬임에 의한 가교결합된 망상구조(semi-IPN)의 3차원 네트워크 구조 형성에 의한 결과로 볼 수 있었다. 특히, CNCs 함량이 증가할수록 하이드로겔의 점탄성 특성들 모두 증가하는 경향이 확인되며 이는 3.2. 절 팽윤도 부분에서 언급한 바와 같이 넓은 비표면적과 다량의 수산기를 가진 CNCs가 PVA 사슬 사이에 침투하여 물리·화학적 결합 및 꼬임 현상을 더욱 강화시켜 분자 사슬의 움직임을 억제하고 하이드로겔에 가해지는 응력을 분산시켜 기계적 특성을 향상시키는 강화제(reinforcement)로써의 역할 때문으로 보여진다. 또 다른 주목할 점은 $\omega$ 와 상관없이 독립적으로 $\mathrm{G}^{\prime}$ 의 일정한 수준의 선형 점탄성 영역(linear viscoelastic region, LVR)을 형성하는 거동을 보인다는 것이다. 만약 분자 내부에 가해지는 힘이 균일하게 분산되지 않고 특정 영역에 집중된다면, 낮은 $\omega$ 에서 분자 내 또는 분자 간 결합이 완전히 또는 부분적인 파괴에 의해 $\mathrm{G}^{\prime}$ 의 일정하지 않고 불규칙한 거동 (fluctuation)이 발생할 수 있다(Mezger, T., 2016, Yue et al., 2016). 따라서 CNCs가 첨가된 하이드로겔에서 G'이 전체 $\omega$ 영역에 서 안정적인 $\mathrm{LVR}$ 형성은 $\mathrm{CNCs}$ 가 PVA 사슬 사이에 고르게 분산되어 있음을 의미한다.

\section{4. 약물 로딩 특성}

본 연구에서 제조된 하이드로겔에 흡착 등온모델인 Langmuir isotherm과 Freundlich isotherm을 적용하여 약물 로딩 성능을 평가하였으며, $\mathrm{CNCs}$ 함량에 따라 각각의 농도에서 살리실산 로딩량을 Fig. 6a에 나타내었다. 살리실산의 로딩량은 $\mathrm{CNCs}$ 를 첨가한 하이드로겔이 첨가되지 않은 하이드로겔보다 더 많이 로딩된 것을 확인할 수 있으며 $10 \mathrm{phr}$ 첨가된 하이드로겔의 로딩량이 $20 \mathrm{phr}$ 첨가된 하이드로겔에 비해 다소 높은 로딩량을 보여주었다. 먼저 CNCs 첨가된 하이드로겔과 CNCs를 첨가하지 않은 하이드로겔의 약물 로딩 특성 비교에 있어서는 수분 흡수와 팽윤도 특성에서 설명한 바와 같이 약물을 흡수하는 내부 공간이 $\mathrm{CNCs}$ 를 첨가하지 않은 하이드로겔이 더 많음에도 불구하고 $\mathrm{CNCs}$ 를 첨가한 하이드로겔에서 더 많은 약물이 로딩된 것이 확인되 었다. 일반적으로 표면 결합 기작에서 표면적이 증가하면 계면에서 흡착양은 증가한다(Zhou et al., 2015; Gao et al., 2017). 본 연구에서는 2.3.1.절과 같이 질소 흡·탈착 법을 이용하여 Baunauer-Emmett-Teller(BET)계산법으로 비표면적 및 기공부피를 도출하여 단위부피당 표면적(surface area to pore volume ratio)을 계산하여 Fig. 7에 나타내었다. $\mathrm{CNC} 0, \mathrm{CNC10}, \mathrm{CNC} 20$ 을 첨가하였을 때 하이드로겔의 단위부피당 $\left(1 \mathrm{~cm}^{3}\right)$ 표면적은 각각 $314,677,61 \mathrm{~m}^{2}$ 으로 계산되었다. 수치적으로 보여주는 것과 
Preparation and Characterization of Cellulose Nanocrystals Reinforced Poly (vinyl alcohol) Based Hydrogels for Drug Delivery System

같이 $\mathrm{CNC10}$ 의 경우 함수율이나 팽윤도에서 설명한 바와 같이 물을 저장할 수 있는 내부 공간이 줄어들었음에도 많은 약물을 흡착될 수 있는 것은 $\mathrm{CNC}$ 가 첨가되면서 내부 표면적이 증가된 것으로 설명된다. 반면, $\mathrm{CNC}$ 과 $\mathrm{CNC} 20$ 의 경우의 비교에 있어서 내부표면적이 $\mathrm{CNC} 20$ 보다 $\mathrm{CNC} 0$ 이 넓음에도 불구하고 약물 흡착량이 낮게 나타났다. 이는 FT-IR 결과에서 보여 주었듯이, $\mathrm{CNCs}$ 를 첨가하면서 $\mathrm{CNCs}$ 표면의 free- $\mathrm{OH}$ 로 인한 하이드로겔의 약물 로딩을 위한 작용점이 증가하였기 때문으로 보인다.

$\mathrm{CNC} 10$ 과 $\mathrm{CNC} 20$ 이 적용된 하이드로겔의 약물 로딩 성능 비교에 있어서 $\mathrm{CNC} 20$ 의 경우가 $\mathrm{CNC10}$ 에 비해 오히려 로딩 효율이 감소한 것을 확인할 수 있었다. 이는 내부표면적의 감소로도 설명될 수 있으며 흡착 기작의 이해를 통해 설명될 수 있다. 약물 로딩에 대한 하이드로겔 내부에서의 흡착 기작의 이해를 위해 2.3.5.절에서 설명한 Langmuir와 Freundlich isotherm 에 적용하고 이에 대한 결과를 Fig. $6 \mathrm{~b}$ 와 $6 \mathrm{c}$ 에 나타내었다. Langmuir isotherm에 적용하여 산출된 $\mathrm{CNC}, \mathrm{CNC10}, \mathrm{CNC} 20$ 의 추세선의 상관계수( $\left(\mathrm{r}^{2}\right.$ : correlation coefficient)는 각각 $0.5946,0.9708,0.0001$ 이었으며, Freundlich isotherm에 적용한 경우 각각 $0.9956,0.9975,0.9690$ 으로 $\mathrm{CNCs}$ 기반 PVA하이드로겔에 대한 살리실산의 로딩 기작은 Langmuir isotherm보다 Freundlich isotherm이 더 적합한 것으로 나타났다. 따라서 적용된 살리실산 분자들이 하이드로겔 내부 계면에 약물 이온이 단분자층으로 결합되어(Langmuir isotherm)있기 보다는 내부의 다양한 기공 계면과 약물 이온 및 약물 이온간의 계면에 전기적 작용, 라디칼, 반데르발스힘 등 이온 상호간의 전기적 세기 차이 등으로 다분자층으로 적층되어(Freundlich isotherm)있음을 확인할 수 있었다(Cho et al., 2013; Tilak et al., 2016; Li and Mooney, 2016). 약물이 CNCs기반 PVA하이드로겔에서 물리화학 적으로 계면에서 다분자층을 형성하여 로딩이 되기 때문에 이를 위한 적절한 공간이 필요한 것으로 보인다. 흡착성능 평가를 위해 수식 (6)로부터 Freundlich 상수 $\mathrm{K}_{\mathrm{F}}$ 와 Freundlich isotherm에서 도출한 실험상수 $\mathrm{n}$ 을 Table 3에 나타내었다. 흡착 성능을 나타내는 $\mathrm{K}_{\mathrm{F}}$ 와 $\mathrm{n}$ 이 $\mathrm{CNC10}$ 이 $\mathrm{CNC} 20$ 보다 더 높은 값을 보여 $\mathrm{CNC10}$ 이 약물 로딩에 좀 더 유리한 조건임을 확인하였다. 따라서 $\mathrm{CNCs}$ 기반 $\mathrm{PVA}$ 하이드로겔에서 기계적 강도를 일정 수준 향상시키면서 약물 로딩량의 증가를 위해서는 $\mathrm{CNCs}$ 함량의 최적화가 필요하며 본 연구에서는 약물 로딩량 측면에서 $\mathrm{CNC10}$ 의 적용이 좀 더 유리한 것으로 확인되었다.

\section{5. 약물 방출 특성}

하이드로겔에 적용된 약물방출 거동은 약물의 효율적 활용 측면에서 상당히 중요한 요소이다. CNCs기반 PVA 하이드로겔의 약물방출 특성을 평가하고 결과를 Fig. 8a에 나타내었다. 흡착 성능 평가를 통해 예상할 수 있듯이 로딩량이 많은 $\mathrm{CNC10}$ 이 적용된 하이드로겔이 방출 양에서도 높은 농도에서 평형에 도달되는 것이 확인되었다. 방출 속도 평가를 위해 방출 데이터들을 유사 1차 반응 속도 모델(Pseudo $1^{\text {st }}$ order model)과 유사 2차 반응 속도 모델(Pseudo $2^{\text {nd }}$ order model)에 적용한 결과를 Fig. $8 \mathrm{~b}$ 와 $8 \mathrm{c}$ 에 각각 나타내었다. 추세선의 상관계수(r': correlation coefficient)의 비교를 통해 1차 반응 모델보다 2 차 반응 모델에 적합한 것을 확인할 수 있었으며 유사 2차 반응 속도 모델을 통해서 약물 방출 속도의 비교 분석을 위해 반응속도 상수 $\mathrm{k}_{2}$ 와 초기 방출 속도를 의미하는 $\mathrm{h}$ 를 계산하고 이에 대한 결과를 Table 4에 나타내었다. CNCs가 첨가될 경우 제조된 하이드로겔의 초기 방출 속도값을 나타내는 $\mathrm{h}$ 값이 감소하는 것이 확인되었다. 이는 $\mathrm{CNCs}$ 의 약물 흡착 기능에 따른 약물 방출 지연으로 설명될 수 있다. CNCs를 첨가하지 않은 경우 대부분의 약물이 하이드로겔 내부 표면에 결합되어 있지 않고 용해되어있기 때문에 삼투압 에 의한 단순 확산으로 방출된다. 반면, $\mathrm{CNCs}$ 가 첨가된 하이드로겔의 경우 앞서 설명한 바와 같이 $\mathrm{CNCs}$ 표면의 많은 작용점과 약물 이온 간의 물리·화학적 결합으로 약물의 방출 속도가 늦어지는 것으로 판단되어진다(Li et al., 2016). 따라서 상기 결과들을 통해 $\mathrm{CNCs}$ 첨가가 PVA 하이드로겔의 약물 방출 지연에 긍정적인 역할을 하는 것을 알 수 있었다.

\section{4. 결 론}

$\mathrm{CNCs}$ 기반 PVA 하이드로겔을 제조하고 물리·화학적 특성 및 기계적 특성을 살펴보았으며, 약물로 살리실산을 적용하여 소수성 약물의 흡착 및 방출 특성을 평가하고 다양한 역학 모델을 사용하여 약물과 하이드로겔의 상호작용을 확인하였다. FT-IR 결과를 통해 가교제인 GA가 첨가된 PVA 하이드로겔 내부가 3차원 가교결합된 망상(semi-IPN)구조를 형성하고 있는 것을 확인하였으며 $\mathrm{CNCs}$ 첨가로 인해 3 차원 구조가 단단하고 치밀해지는 것을 확인하였다. 이러한 $\mathrm{CNCs}$ 의 역할로 인해 수분 흡수도와 팽윤도가 감소되는 경향을 보였으며 점탄성 특성이 높아지는 것으로 하이드로겔의 기계적 특성이 향상되는 것을 확인하였다. 제조된 하이드로겔의 약물 로딩 거동 분석을 통해 흡착 등온모델인 Langmuir isotherm과 Freundlich isotherm 을 적용하였으며 그 결과 약물 로딩 거동이 Langmuir보다 Freundlich isotherm에 더 적합한 것으로 나타났다. 이를 통해 제조된 하이드로겔 내부에서 약물이 단분자층이 아닌 다분자층으로 복합적으로 물리·화학적 결합을 통해 로딩이 되는 것을 예상할 수 있었다. CNCs 첨가로 인해 하이드로겔의 3차원 네트워크 구조 형성에 참여하지 않은 수산기가 증가하면서 약물 로딩량이 증가하는 것을 확인할 수 있었으며, $\mathrm{CNC} 20$ 에 비해 내부 표면적이 넓어진 $\mathrm{CNC} 10$ 이 약물 로딩량이 높은 것을 확인할 수 있었다. 또한 약물의 방출 특성 분석 결과 $\mathrm{CNCs}$ 의 첨가로 인해 약물의 지연 방출에 대한 효과를 확인할 수 있었으며, 이를 통해 결정형 나노셀룰로오스인 $\mathrm{CNCs}$ 의 서방형 약물전달시스템의 핵심 소재로써 높은 잠재 가능성을 확인할 수 있었다. 